\begin{tabular}{cc} 
Revista de & Journal of Integrated \\
GESTÃO COSTEIRA Integrada COSTAL ZONE MANAGEMENT \\
\hline
\end{tabular}

\title{
Processes controlling the seasonal cycle of wave-dominated inlets*
}

\author{
Xavier Bertin ${ }^{@}$, a; André B. Fortunato ${ }^{\mathrm{b}}$; Guillaume Dodet $^{\mathrm{a}}$
}

\begin{abstract}
This paper reviews the physical processes controlling wave-dominated inlets, based on several studies conducted at two inlets located on the West Coast of Portugal. Once the observed hydrodynamics and morphological changes are reasonably simulated, numerical experiments are performed to explain the development of the inlet during fair weather conditions and its shoaling and closure during winter storms. The former behaviour is explained by a tidal distortion that promotes ebbdominance while the latter is explained by the combination of several wave-related processes: (1) the "bulldozer effect" due to the shore-normal component of wave forces; (2) the presence of lateral barotropic pressure gradients, accelerating longshore flows towards the inlet; (3) wave blocking during the ebb and (4) a rise in mean sea level, peaking in late autumn. Recent results also suggest that infragravity waves may play a major role.
\end{abstract}

Key words: Tidal inlets, wave-induced processes, wave blocking, infragravity, Óbidos lagoon, Albufeira lagoon.

\section{RESUMO}

Processos que controlam o ciclo sazonal de embocaduras dominadas pelas ondas.

Apresenta-se uma revisão dos processos físicos que controlam a dinâmica de embocaduras dominadas pelas ondas, com base em vários estudos conduzidos em duas embocaduras localizadas na zona costeira centro de Portugal. As análises são conduzidas com modelos morfodinâmicos, que reproduzem adequadamente a hidrodinâmica e a evolução morfológica observadas. Experiências numéricas são efetuadas para explicar o desenvolvimento das embocaduras durante o verão marítimo e a sua colmatação e fecho durante tempestades de inverno. O primeiro comportamento é explicado pela distorção da maré que promove a dominância da vazante, enquanto o segundo se explica pela combinação de vários processos relacionados com a agitação marítima: (1) o "efeito bulldozer" devido à componente transversal à costa das forças devidas às ondas; (2) a presença de gradientes laterais de pressão barotrópica, que aceleram as correntes longitudinas em direcção à embocadura; (3) o bloqueamento das ondas durante a vazante e (4) o ciclo sazonal do nível médio do mar, cujo pico ocorre no outono. Resultados recentes sugerem ainda que as ondas infragravíticas podem ter um papel importante nesta dinâmca.

Palavras-chave: embocaduras de maré, processos induzidos pelas ondas, bloqueamento das ondas, ondas infragraviticas, lagoa de Óbidos, Lagoa de Albufeira.

\footnotetext{
(a) Corresponding author to whom correspondence should be addressed.

${ }^{\mathrm{a}}$ UMR 7266 LIENSs, CNRS-La Rochelle University, 2 rue Olympe de Gouges, 17000 La Rochelle, France. e-mails: Bertin <xbertin@univlr.fr>; Dodet <gdodet01@univ-lr.fr>

${ }^{\mathrm{b}}$ Laboratório Nacional de Engenharia Civil, Avenida do Brasil, 101, Lisboa, Portugal. e-mail: <afortunato@lnec.pt>
}

* Submission: 13 JUN 2014; Peer review: 25 JUL 2014; Revised: 11 DEC 2014; Accepted: 13 DEC 2014; Available on-line: 16 DEC 2014
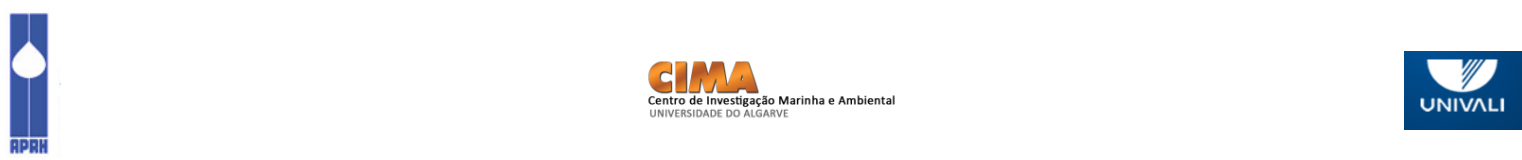


\section{Introduction}

The economic and environmental importance of tidal inlets has been growing worldwide, while their sustainable management faces many conflicting challenges, such as the maintenance of open navigation routes, the stability of the adjacent shoreline or the water renewal in the back-barrier lagoons. The combined action of waves and tides and the presence of shallow channels often drive a fast and intense sediment dynamics and make their behaviour difficult to predict. These problems are particularly relevant at wave-dominated inlets, where this intense dynamics can drive fast and large morphological changes within a few days/weeks. Eventually, wave-dominated inlets can episodically or seasonally close, although the responsible physical processes remain only partly understood.

To improve the understanding of tidal inlet dynamics, a promising avenue is the development and application of morphodynamic modelling systems. These modelling systems consist of a set of modules to simulate tidal hydrodynamics, wave propagation, sediment transport and bottom evolution. The morphodynamic modelling of tidal inlets already met several successes over the last decade (Cayocca, 2001; Dastgheib et al., 2008; Bertin et al., 2009a; Bruneau et al., 2011). Nevertheless, to date, the successful simulation of tidal inlet closure is restricted to simplified/empirical approaches (Ranasinghe et al., 1999) and/or synthetic tidal inlets (Walstra et al., 2009). This problem suggests that the dominant physical processes are not all captured by most modelling systems. However, the numerical modelling of wave-dominated inlets made significant progresses over the last decade, and resulted namely in an improved understanding of the main physical processes that drive morphological changes.

This paper reviews the knowledge gained from previous modelling-based studies performed at two wavedominated inlets located on the west coast of Portugal (Bertin et al., 2009b; Bruneau et al., 2011; Dodet et al., 2013; Fortunato et al., 2014) and synthesizes the physical processes controlling the seasonal cycle of wavedominated inlets, including their enlargement during fair weather conditions and their shoaling or even closure during winter months.

\section{Study sites}

This study is based on results obtained at two wavedominated inlets located on the West Coast of Portugal: the Albufeira Lagoon Inlet and the Óbidos Lagoon Inlet (figure 1). Tides are semi-diurnal and range from $0.5 \mathrm{~m}$ to $3.5 \mathrm{~m}$ (meso-tidal). When tides propagate into the lagoons, the semi-diurnal tidal constituents are severely damped, with the amplitude of M2 typically decreasing by 50 to $80 \%$ (figure 1 ) at both lagoons (Oliveira et al., 2006; Bertin et al., 2009b; Dodet et al., 2013). Tidal amplitude in the lagoon experiences a seasonal cycle, with a maximum at the end of the summer and a minimum at the end of the winter at Óbidos. In the Albufeira Lagoon Inlet usually closes in autumn (figure 1). In contrast to semi-diurnal constituents, quarterdiurnal and fortnightly non-linear tidal constituents develop inside the lagoons, resulting in a strongly distorted tidal signal, with ebb lasting 7 to 8 hours and floods 4.5 to 5.5 hours. Freshwater discharges are usually negligible compared to the dynamics induced by waves and tides, particularly in Albufeira where the lagoon is closed from autumn to mid-spring.
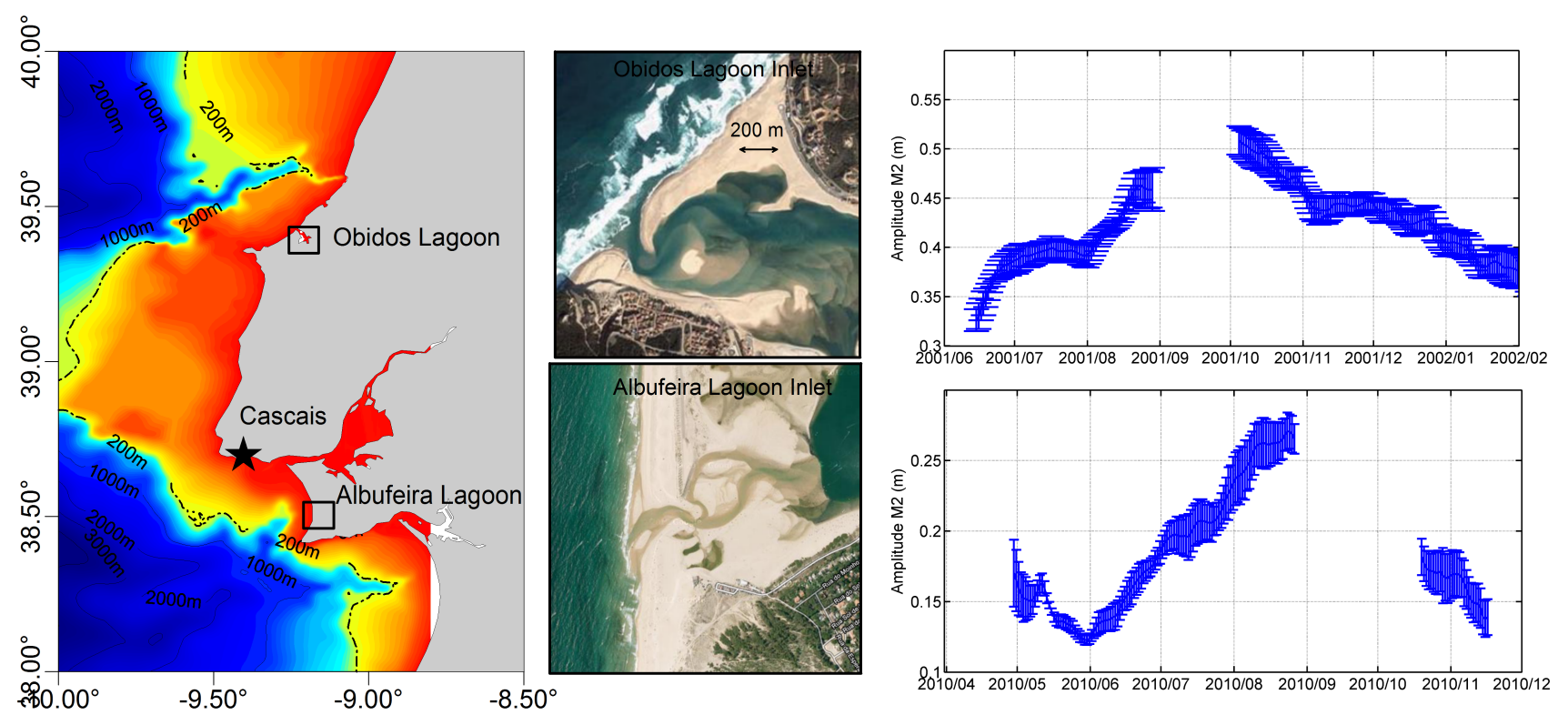

Figure 1 - Bathymetric map of the central western coast of Portugal, aerial view of the Albufeira and Óbidos lagoon inlets and time-series of the amplitude of the constituent M2 inside those lagoons based on water level measurements.

Figura 1 - Batimetria da zona centro da costa Portuguesa, vista aérea das embocaduras das lagoas de Óbidos e Albufeira e séries temporais da amplitude da constituinte M2 nestas lagunas, baseadas em medições de altura de água. 
The continental shelf in front of both inlets is very narrow $(<20 \mathrm{~km})$, which causes these inlets to be exposed to a very energetic wave climate, particularly in winter. Based on a 57-year wave numerical hindcast (Dodet et al., 2010), the mean annual deep water $\left(10.0^{\circ} \mathrm{W}\right.$; $38.0^{\circ} \mathrm{N} ; \sim 3000 \mathrm{~m}$ deep) significant wave height $\left(\mathrm{H}_{\mathrm{S}}\right)$, mean direction (MWD) and peak period $\left(\mathrm{T}_{\mathrm{P}}\right)$ are respectively $1.9 \mathrm{~m}, 312^{\circ}$, and $10.5 \mathrm{~s}$. During winter (resp. summer) the corresponding values are: $2.5 \mathrm{~m}, 305^{\circ}$, and $12.1 \mathrm{~s}$ (resp. $1.3 \mathrm{~m}, 319^{\circ}$ and $8.4 \mathrm{~s}$ ). Also, the presence of coarse sediments (i.e., $\mathrm{d} 50$ in the range $0.5-1.0 \mathrm{~mm}$ ) causes the adjacent beaches to display steep faces, which favour energetic wave breaking and large sediment transport rates.

This severe wave climate combined to the meso-tidal range and shallow channels leads to very dynamic inlets, with channel migration which can reach $50 \mathrm{~m} . \mathrm{week}^{-1}$ (Fortunato et al., 2014). Both systems are characterized by a seasonal cycle, with an enlargement and deepening of the main channel during the summer period and a strong shoaling during the winter period (Bertin et al., 2009b; Fortunato et al., 2014).

\section{Data and methods}

\subsection{Field measurements}

At both sites, several field campaigns were carried out over the last decade, where pressure sensors, electromagnetic current-meters and ADCPs were deployed over both the flood and the ebb deltas, in order to characterize wave and tide transformation along their propagation through the inlets. Pressure sensors were also deployed during several months inside the lagoons in order to characterize properly the seasonal evolution of tidal amplitude. Finally, repetitive bathymetric and topographic surveys were carried out to quantify the fast morphological changes observed at both sites. De- tails on these field measurements and data processing can be found in Oliveira et al. (2006), Bertin et al. (2009b), Dodet et al. (2013) and Fortunato et al. (2014).

\subsection{Numerical modelling system}

The numerical results presented in this study rely on the unstructured-grid modelling systems MORSYS2D (Fortunato \& Oliveira, 2004; Bertin et al., 2009b) and SELFE (Dodet et al., 2013; Roland et al., 2012). These modelling systems share the same philosophy and fully couple a spectral wave model (either SWAN, Boiij et al., 1999; or WWMII, Roland et al., 2012), a 2DH circulation model (either ELCIRC, Zhang et al., 2004; or SELFE, Zhang et al., 2011) and a sediment transport/bottom update model (either SAND2D, Fortunato \& Oliveira, 2004; Bertin et al., 2009b; or SED2D, Dodet, 2013). For both sites, the unstructured grids have a spatial resolution ranging from about $500 \mathrm{~m}$ along the open boundary to $5 \mathrm{~m}$ along the coast in order to adequately represent the surf zone and wave-induced flows. The numerical procedure can be seen on figure 2 and includes three main steps:

1 - First, the propagation of short waves is simulated using a spectral wave model forced along its open boundary by time-series of spectra originating from the regional wave model of Dodet et al. (2010). The spectral wave model is fed by fields of elevation and currents originating from the circulation model.

2 - The horizontal circulation is simulated using SELFE or ELCIRC, which is forced along its open boundary by the 16 main tidal constituents whose amplitude and phase are computed with the regional tidal model of Bertin et al. (2012). A full coupling is achieved with the spectral wave model through gradients of radiation stresses, horizontal viscosity and bottom friction.

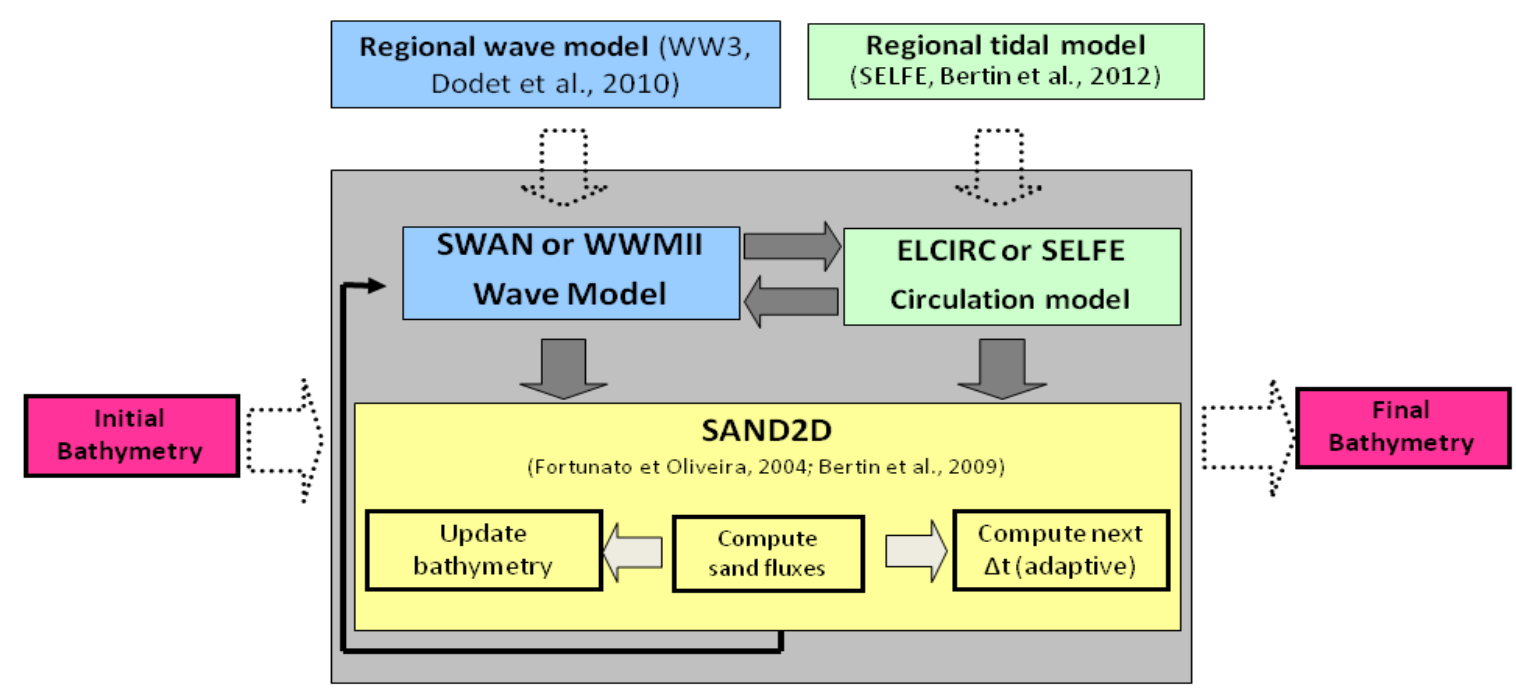

Figure 2. Flowchart of the modelling system procedure.

Figura 2. Esquema do modelo morfodinâmico. 
3 - Sand fluxes are computed based on time-series of currents, water levels and wave parameters by means of total transport empirical formulae (e.g. Soulsby and Van Rijn, Soulsby, 1997). The Exner or sediment continuity equation is then solved using a node-centred finite volume method.

\section{Results and discussion}

Previous studies conducted by our team have demonstrated that our modelling system was capable to reproduce waves and currents at the studied sites with a normalized root mean square error (hereafter NRMSE) of the order of $10-15 \%$. Water levels are predicted more accurately, with a NRMSE of the order of $5 \%$ (Bertin et al., 2009b; Bruneau et al., 2011; Dodet et al., 2013). Morphological predictions have larger errors and their accuracy deteriorates with time along the simulation, although the main patterns are reproduced qualitatively. In particular, the enlargement of the main channel during fair weather conditions and its shoaling during winter months are well captured (Bertin et al., 2009a; Bruneau et al., 2011). In some cases, the model can also reproduce the meandering of the channels (Bruneau et al., 2011) and the inlet migration (Bertin et al, 2009c). Under these conditions, the dominant physical processes responsible for these morphological changes are assumed to be well captured by our modelling system. In this section, we present the results of numerical experiments that aim at describing and quantifying these processes.

\subsection{Inlet development during fair weather condi- tions}

In order to understand why wave-dominated inlets enlarge during fair weather conditions, we performed synthetic simulations at the Óbidos lagoon under tidal forcing only. We considered simplified tides represented by $\mathrm{M} 2$ only, whose amplitude was set to $0.75 \mathrm{~m}$ (mean neap conditions) and $1.5 \mathrm{~m}$ (mean spring conditions). Time series of water depth at the inlet reveal firstly that tides are strongly distorted at the inlet, with a shorter flood than ebb. This distortion is stronger for spring tides with an ebb duration of $7.5 \mathrm{~h}$ and a flood duration of $5.0 \mathrm{~h}$. According to classical theories on tidal distortion for estuaries (e.g., Friedrichs \& Aubrey, 1988), longer ebb would result in higher current velocities during flood. Yet, the opposite behaviour is observed at both inlets, with slightly larger velocities occurring during the ebb and lasting more than maximum flood velocities (figure 3-C). This paradoxical behaviour is related to the fact that maximum flood occurs for a water depth twice as large as maximum ebb, which causes ebb currents to be stronger so that mass conservation is ensured. Higher velocities in shallower depth during ebb cause associated sand fluxes to be 1.4 to 2.0 times larger than on flood (figure 3-D). As a consequence, under tidal forcing only, the Óbidos and Albufeira Lagoon inlets remain strongly ebb-dominated from velocity and sediment transport viewpoints, with a
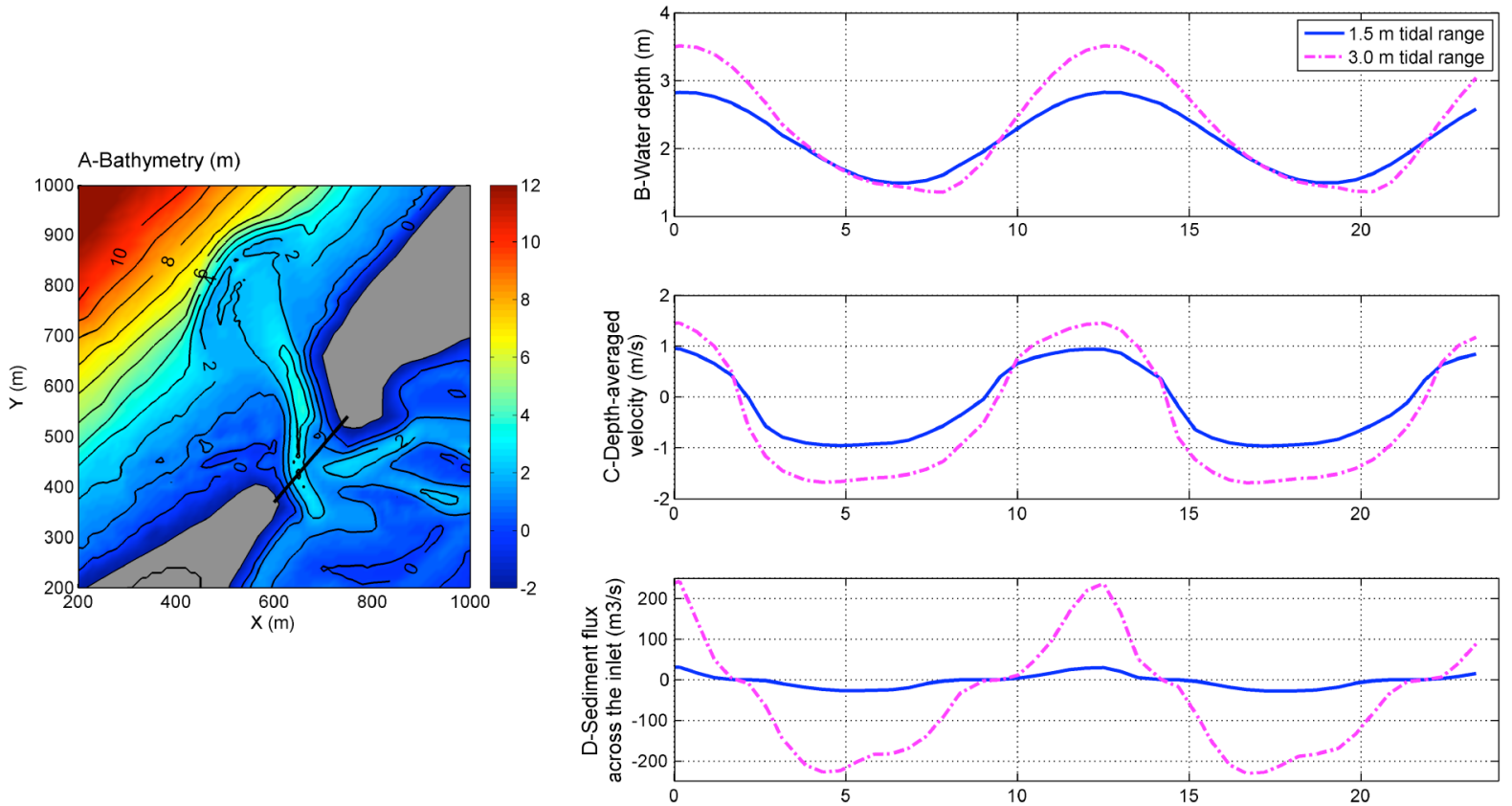

Figure 3 - (A) Bathymetry of the Óbidos Lagoon Inlet in July 2001 showing the profile where model outputs were averaged, (B) mean water depth across the inlet, (C) mean depth-averaged velocity across the inlet and (D) sediment fluxes integrated accross the inlet.

Figura 3 - (A) Batimetria da embocadura da lagoa de Óbidos em julho de 2001, mostrando o perfil onde os resultados do modelo foram integrados, (B) profundidade média na embocadura, (C) média das velocidades médias na vertical e (D) fluxos sedimentares integrados através da embocadura. 
stronger ebb-dominance for spring tides compared to neap tides. This ebb-dominance favours the flushing of sediments at the inlet mouth and explains why wavedominated inlets enlarge during fair weather conditions, when wave-related processes are not dominant.

\subsection{Inlet shoaling during winter period}

\subsubsection{The "bulldozer effect"}

Field observations revealed that wave-dominated inlets in Portugal experience shoaling during winter storms, occasionally leading to their closure (Bertin et al., 2009b; Fortunato et al., 2014). In order to understand which wave-related processes can induce the shoaling of wave-dominated inlets during winter storms, we performed a synthetic simulation at the Óbidos Lagoon considering energetic $\left(\mathrm{H}_{\mathrm{s}}=3.0 \mathrm{~m} ; \mathrm{T}_{\mathrm{p}}=12 \mathrm{~s}\right)$ shorenormal wave conditions with a $1.1 \mathrm{~m}$ tidal amplitude (mean annual tidal range). Figure 4-B shows that wave dissipation over the ebb-delta and at adjacent beaches results in large gradients of radiation stress (wave forces) directed onshore (figure 4-C). These forces induce a setup reaching $0.25 \mathrm{~m}$ at adjacent beaches, which itself induces a barotropic pressure gradient. At adjacent beaches, this barotropic pressure gradient nearly balances wave forces (figure 4-F) and the residual forces are very weak. In front of the inlet, large wave forces on the ebb delta are no longer balanced by a barotropic pressure gradient because the wave-induced setup is spread within the lagoon. As a result, a strong residual forcing occurs on the ebb delta, which was referred to as "bulldozer effect" by Hageman (1969). This phenomenon is well captured by our modelling system, which is able to reproduce the migration of ebb-delta sandbars towards the lagoon (Bertin et al., 2009b).

\subsubsection{Lateral barotropic pressure gradients}

Figure 4-D shows that wave forces induce a setup at adjacent beaches of the order of $10 \%$ the wave height at the breaking point. At the inlet, this setup is interrupted, which induces a lateral barotropic pressure gradient. This barotropic pressure gradient is not compensated by any wave forces so that a strong residual forcing directed towards the lagoon occurs on both sides of the inlet. These pressure forces result in an acceleration of longshore currents towards the lagoon, which tend to push large quantities of sediments into the lagoon. At high tide, this phenomenon is further enhanced by wave refraction over the ebb-delta, which causes wave-induced longshore currents to converge towards the inlet (not shown, Bertin et al., 2009b).
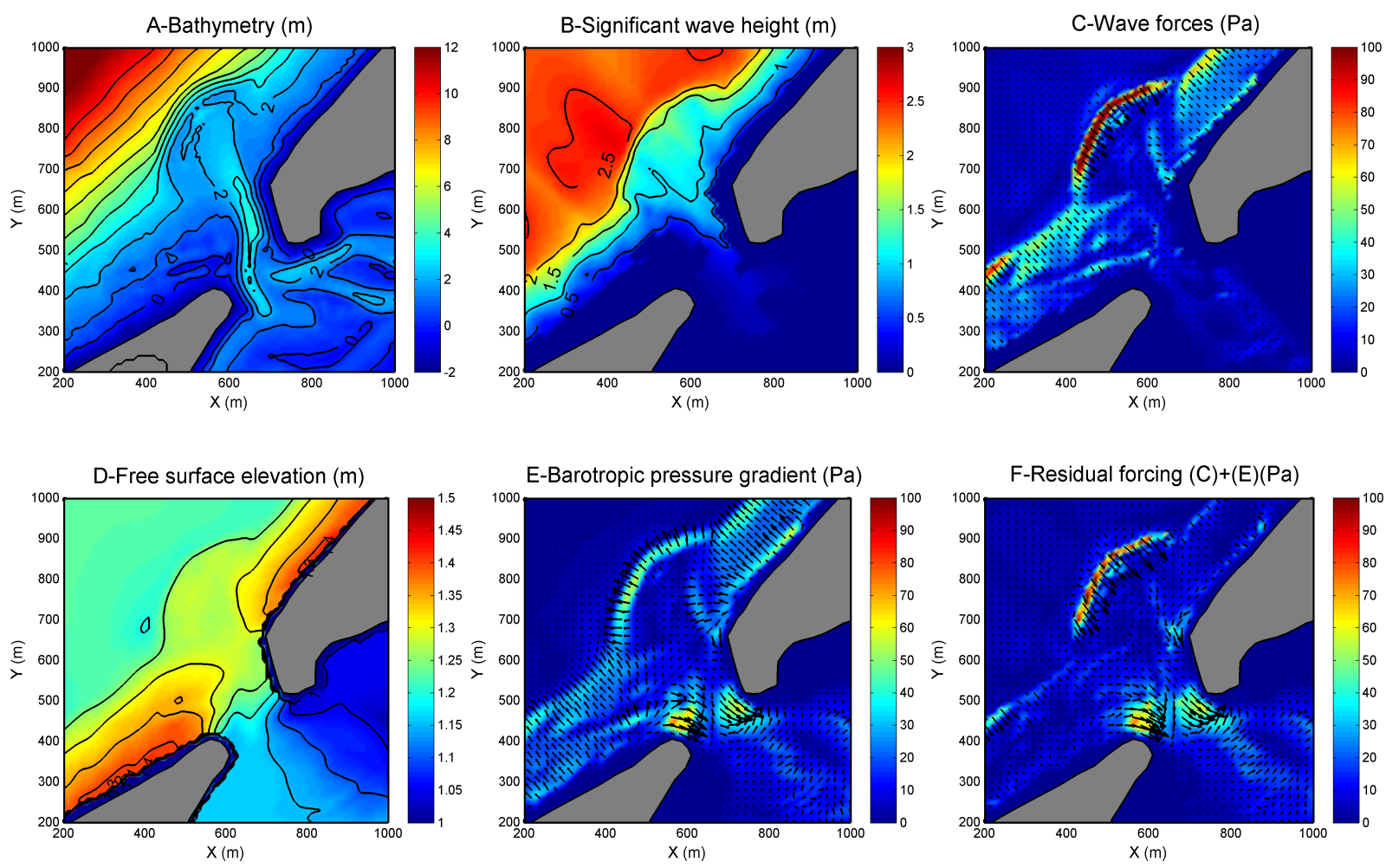

Figure 4 - (A) Bathymetry (m), (B) significant wave height (m), (C) wave forces (Pa), (D) free surface elevation $(\mathrm{m}),(\mathrm{E})$ barotropic pressure gradient $(\mathrm{Pa})$ and $(\mathrm{F})$ resultant forces $(\mathrm{Pa})$ at the Óbidos Inlet for shore-normal offshore waves of $\mathrm{Hs}=3.0 \mathrm{~m}$.

Figura 4 - (A) Batimetria (m), (B) altura significativa (m), (C) forças devidas às ondas (Pa), (D) elevação da superfície livre (m), (E) gradiente de pressão barotrópica (Pa) e (F) resultante das forças (Pa) na embocadura da Lagoa de Óbidos para ondas incidentes perpendiculares à costa com $\mathrm{Hs}=3.0 \mathrm{~m}$. 


\subsubsection{Wave blocking during ebb}

A field campaign was carried out at the Albufeira Lagoon Inlet in September 2010 where pressure transducers were deployed on both the ebb and the flood deltas (figure 5-A). A time series of significant wave heights on the flood delta (PT2, figure 5-B) revealed firstly that the wave height inside the lagoon is modulated along the tidal cycle and becomes almost nil at low tide. This behaviour is due to wave energy dissipation by breaking on the ebb delta, which increases as water level decreases. Furthermore, $\mathrm{H}_{\mathrm{s}}$ are not symmetrical for a given water level and experience a fast drop when ebb currents start to establish. To better understand this behaviour, the modelling system was run with and without current feedback on wave propagation. Figure 5-B shows that the fast drop in $\mathrm{H}_{\mathrm{s}}$ is only reproduced if the feedback of currents in the wave model is taken into account. The modelling results show firstly that waves propagating against currents experience whitecapping dissipation (Dodet et al., 2013). This process is represented in our modelling system following the approach of Westhuysen (2012). Two hours after the beginning of the ebb, wave heights inside the lagoon become almost nil. The analysis of modelled tidal currents reveals that, in the inlet main channel, waves propagate against tidal currents locally exceeding $2.0 \mathrm{~m} / \mathrm{s}$. Such large velocities almost correspond to the wave group velocity, which causes the waves to be blocked locally (Dodet et al., 2013).
Dodet el al. (2013) investigated the impact of these phenomena on the sediment dynamics of tidal inlets. On flood, the presence of waves superimposed on tidal currents in the main channel increases sediment transport rates. During the ebb, waves are first dissipated by whitecapping, and then blocked, so that the transport capacity of ebb currents is no longer enhanced. Over a tidal cycle, these processes decrease the capacity of the inlet to flush sediments out of the lagoon. Nevertheless, further research is needed to determine whether this conclusion can be extended to other wave conditions and inlet configurations. Further experiments will have to be carried out during more energetic wave conditions and/or at wider inlets, where larger waves can propagate in the main channel.

\subsubsection{Infragravity waves}

A spectral analysis of pressure transducer and current data collected at the Albufeira Lagoon Inlet in September 2010 (figure 5-A) showed that a significant part of spectral energy was found in the infragravity band $(0.004 \mathrm{~Hz}-0.04 \mathrm{~Hz}$, figure 6). This phenomenon is particularly clear on the third tidal cycle, where more energy is found on the infra-gravity band than the gravity band (figure 6). This low-frequency energy is expressed as low-frequency fluctuations of the free-surface elevation, wave heights and current velocities. These fluctuations were particularly visible in the measured data at PT2, when comparing the 1-min running averaged with
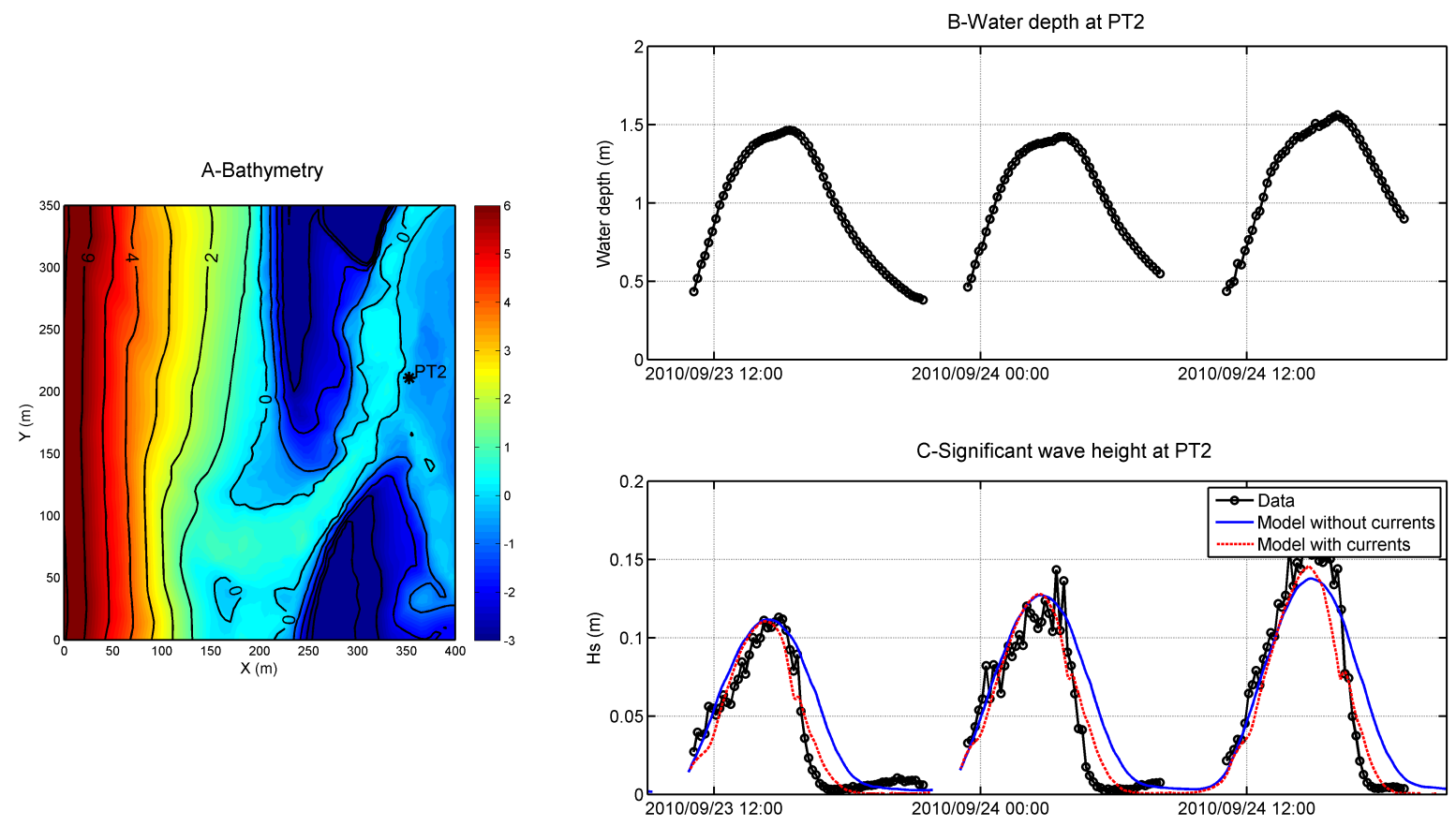

Figure 5 - (A) Bathymetry of the Albufeira Lagoon Inlet, (B) measured water depth and (C) measured and modelled time series of significant wave heights on the flood delta in September 2010.

Figura 5 - (A) Batimetria da embocadura da Lagoa de Albufeira, (B) altura de água medida e (C) séries temporais, medidas e simuladas, da altura significativa no banco de enchente em setembro de 2010. 
the 60 min running averaged time-series (figure 7). Such oscillations reached up to $10 \%, 20 \%$ and $50 \%$ of the $60 \mathrm{~min}$ filtered signal, for free-surface elevation, wave heights and currents, respectively. While the physical processes that explain these infragravity fluctuations require further investigation, Dodet (2013) estimated their contribution to the sediment dynamics of the inlet - aside from the effect of wave-current interactions. In this context, the total transport induced by waves and currents was computed at PT2 (figure 5A), using the Soulsby and Van Rijn formula (Soulsby, 1997), fed on the one hand by the 60 min filtered timeseries of elevation, $\mathrm{H}_{\mathrm{s}}$ and velocity (the wave orbital velocity was computed using the linear theory) and on the other hand the $1 \mathrm{~min}$ filtered time-series that include the low-frequency oscillations. During the third tidal cycle, where low frequency fluctuations were the largest, the total sediment transport was locally up to eight times as large when taking into account low-frequency fluctuations and twice as large when integrated over a tidal cycle.

It can also be noted that these low-frequency fluctuations appear mostly during the flood, which suggests that infragravity waves are also damped or blocked by ebb currents. Therefore, in terms of inlet morphodynamics, this behaviour implies that these low-frequency fluctuations rather contribute to fill the lagoon with sediments. This process can play a key role during storms, where it can significantly contribute to inlet closure. However, according to the authors' knowledge, it is the first time that the importance of infragravity waves at tidal inlets is demonstrated and thus further research is needed. Namely, comparisons at other sites are required and the implementation of infragravity waves in modelling systems (e.g., Roelvink, 2009) would be a promising perspective.

\subsubsection{Variations in mean-sea level}

Previous studies have shown that at both Óbidos (Bertin et al., 2009b) and Albufeira (Dodet et al., 2013), the setup induced by wave breaking in front of the inlet propagates inside the lagoon and reaches roughly $10 \%$ of the wave height at breaking. Energetic waves and winter storms can thus induce variations of mean sealevel (hereafter MSL) of a few tens of centimetres. Since both inlets are very shallow, such variations in MSL are expected to impact tidal asymmetry and thereby sediment dynamics significantly. To better quantify this phenomenon, morphodynamic simulations were performed at the Óbidos inlet under tidal forcing only and varying MSL between $-0.2 \mathrm{~m}$ and $+0.4 \mathrm{~m}$. Changes in tidal asymmetry were characterized through the ratio between the amplitude of M4 and M2. The impact on sediment transport was characterized through the ratio between the sediments flushed at the inlet during the ebb and entering the lagoon during the flood. Results show that higher water levels reduce tidal asymmetry (figure 8-B), strongly decrease ebbdominance, and the ratio between ebb and flood sand transport across the inlet tends to 1 (figure 8-C).

Because floods occur, on average, at higher water levels than ebbs (Fortunato \& Oliveira, 2007), the water flows more freely into, than out of, the lagoon. Floods are

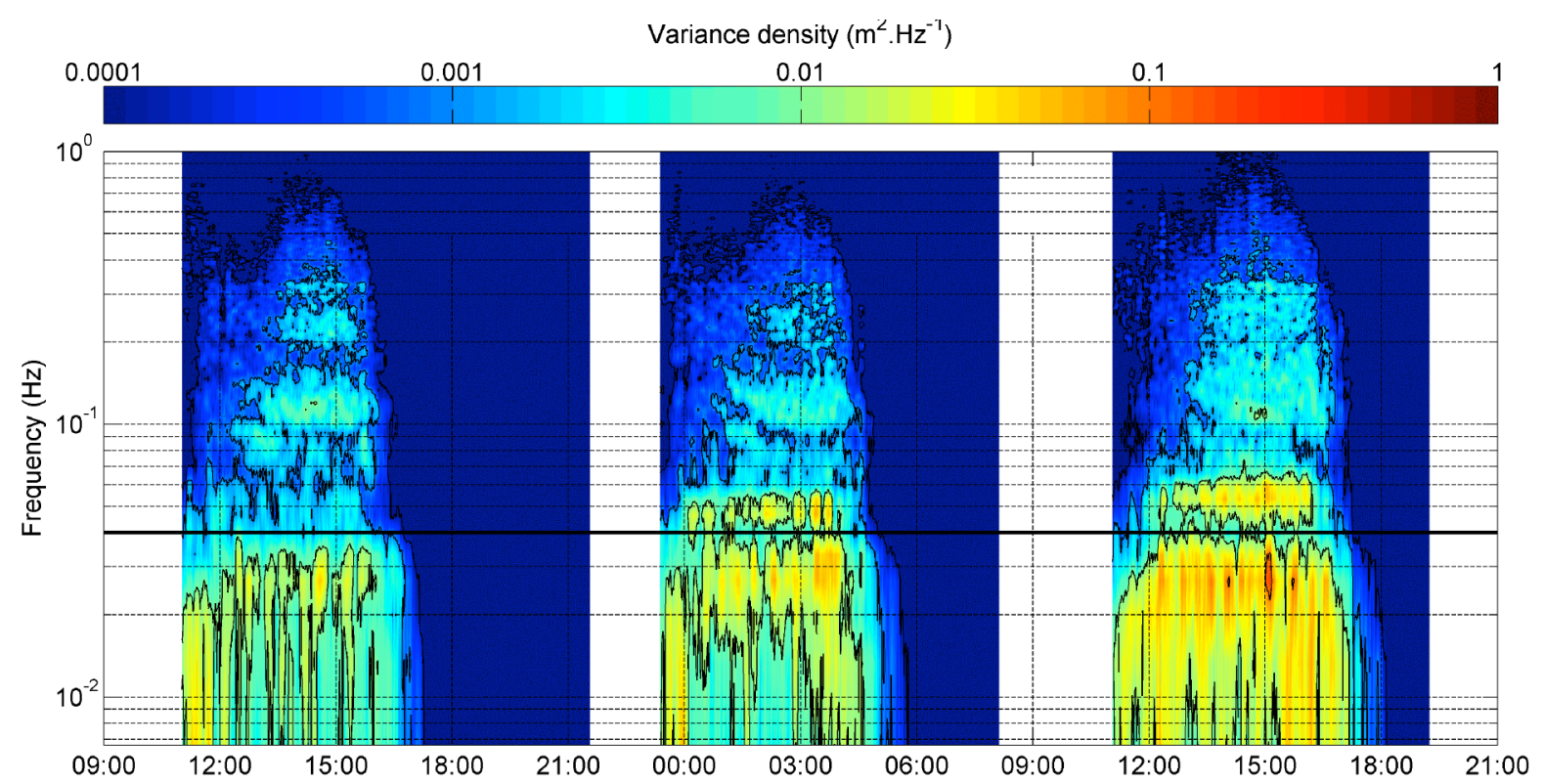

Figure 6 - Energy spectra of the free surface elevation at PT2 (figure 5A), showing that a large part of the energy is located in the infragravity band.

Figura 6 - Espectro de energia da superficie livre na estação PT2 (Figura 5A), mostrando que grande parte da energia está localizada na banda infragravítica. 

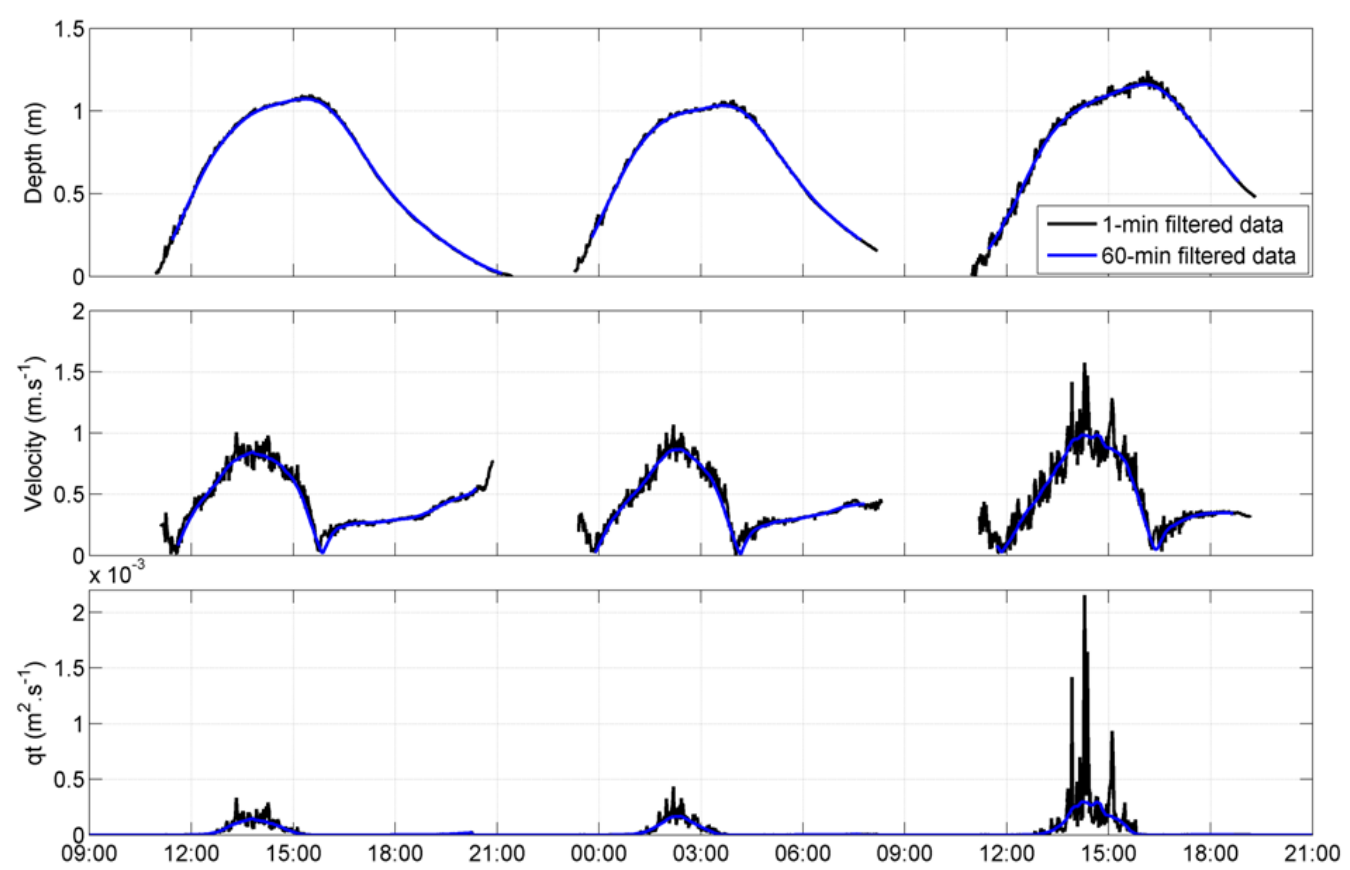

Figure 7 - 1-min and 60-min running averaged time-series of water depth, velocity, and total sediment transport (Qt) at PT2 (figure 5).

Figura 7 - Médias de banda móvel de 1 e 60 minutos da altura de água, velocidade e fluxo sedimentar total (Qt) em PT2 (Figura 5).
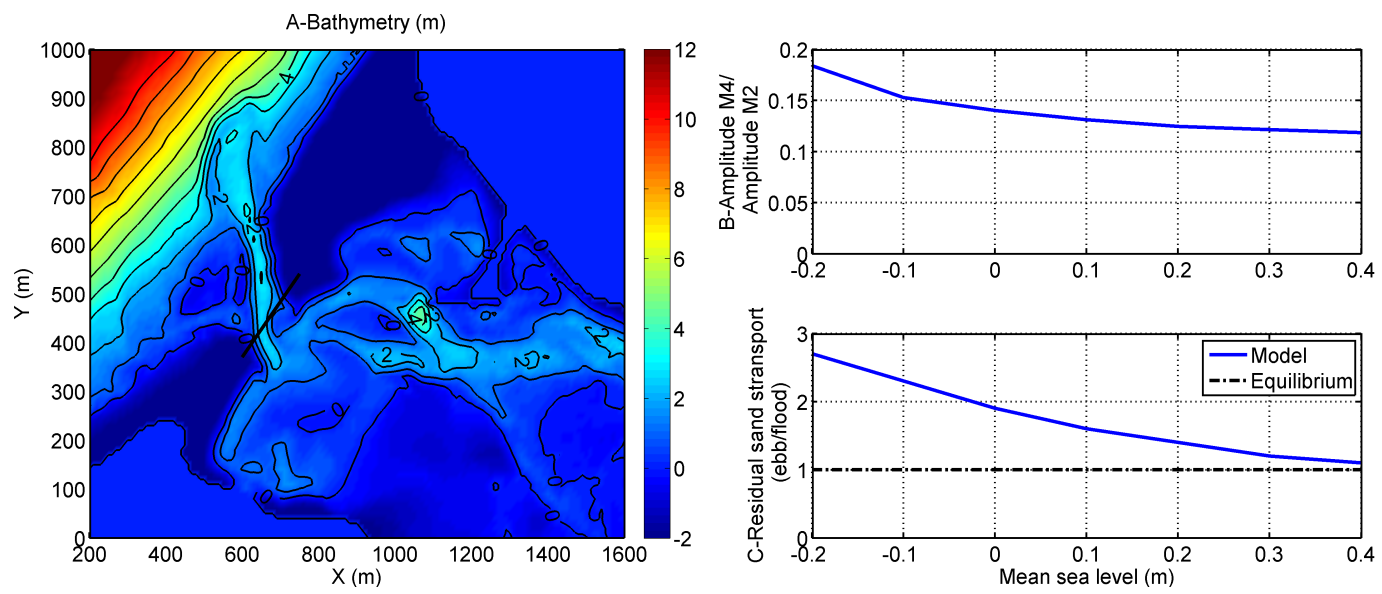

Figure 8 - (A) Bathymetry of the Óbidos lagoon with the cross-section where sand transport was integrated, (B) ratio between the amplitudes of M4 and M2 in the lagoon and (C) residual sand transport across the inlet (ebb/flood).

Figura 8 - (A) Batimetria da Lagoa de Óbidos mostrando a secção transversal onde o transporte de areia foi integrado, (B) quociente entre as amplitudes da M2 e da M4 na laguna e (C) transporte de areia residual através da embocadura (vazante/enchente).

therefore shorter than ebbs, which would contribute to higher velocities on flood than on ebb. However, mass conservation also implies that the higher water depths on flood reduce the flood velocities relative to the ebb currents. While the former process is usually the dominant one in large estuaries and inlets, we found the latter to dominate in our two shallow lagoons. Raising the mean sea level has therefore two opposite effects. On the one hand, the higher water depth in the inlet facili- tates the water outflow, thereby reducing the ebb duration and the flood dominance. For instance, the mean water level in the lagoon explains $50 \%$ of the difference between ebb and flood durations in the Albufeira lagoon (Fortunato et al., 2014), with longer floods corresponding to higher mean water levels. On the other hand, the relative differences between the water depths on ebb and flood decrease, which reduces the distinction between ebb and flood velocities due to continuity. 
This process is illustrated on Figure 8C. Since tidal asymmetry is dominated by the mass conservation effect in shallow lagoons, raising the mean water level reduces the predominance of ebb currents in these systems.

In addition to the wave-induced setup which develops in the nearshore, MSL experiences a seasonal cycle along the west coast of Portugal. A permanent tide gauge is located in the Cascais marina between both studied sites (figure 1). A Demerliac filter was applied to a time series of water level originating from this station and daily and monthly MSL were computed (figure 9). This figure reveals that mean sea-level reaches its maximum in autumn and its minimum in late winter, with a $0.2 \mathrm{~m}$ difference between both. Although outside the scope of this study, investigations in progress in our team show that this seasonal cycle results from the superimposition of atmospheric forcing and steric effects. The Albufeira Lagoon Inlet usually closes in autumn (e.g., Dodet et al., 2013): it is likely that the decrease in ebb-dominance related to a higher MSL can contribute significantly to inlet closure.
Besides the rise in mean sea level associated to seasonal effects and storms, significant fortnightly variations of water level can also occur inside the lagoon due to nonlinear tides. These fortnightly tides are particularly strong in very shallow systems. In the Albufeira lagoon, their amplitude reaches several tens of centimetres, with crests occurring on spring tides and troughs on neap tides (Fortunato et al., 2014). The importance of these constituents is shown at the Albufeira lagoon in a simulation forced by M2 and S2 tidal constituents. The amplitude of the fortnightly constituent MSf reaches about $15 \mathrm{~cm}$. The associated velocity at the tidal inlet throat exceeds $30 \mathrm{~cm} / \mathrm{s}$. This velocity is in phase with the elevations (Figure 10B), indicating that this constituent is a standing wave. These strong velocities affect the sediment fluxes significantly. On spring tides they increase sediment fluxes on ebb and decrease them on flood (Figure 10C). The opposite occurs on neap tides (Figure 10D). Hence, ebb dominance from a sediment viewpoint is not only higher on spring tides due to the stronger fourth-diurnal constituents, but also due to the fortnightly constituents.

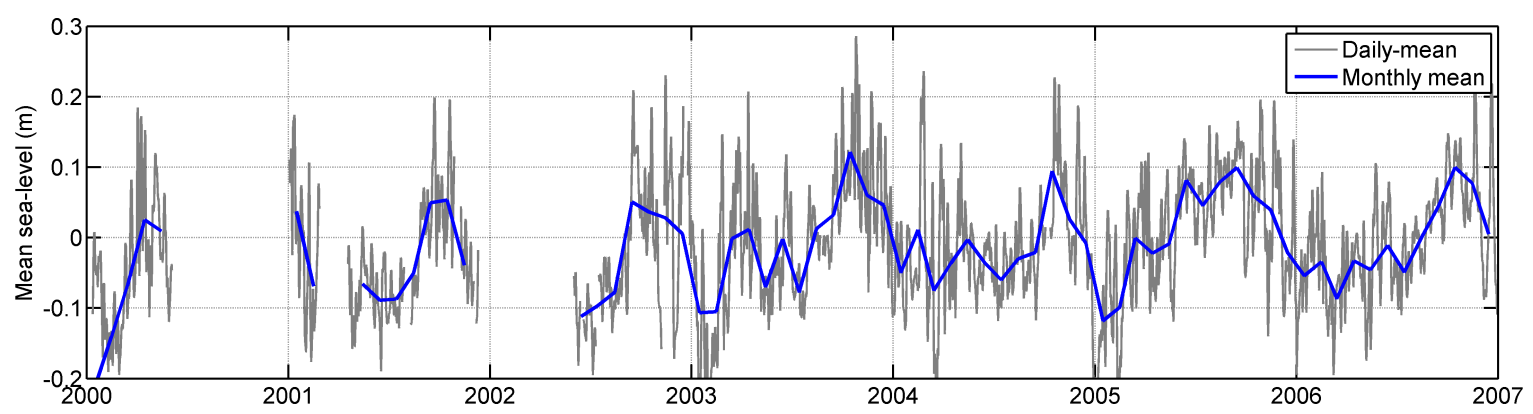

Figure 9 - Daily and Monthly mean sea-level in Cascais between 2000 and 2007.

Figura 9 - Médias diárias e mensais do nível do mar em Cascais entre 2000 e 2007.
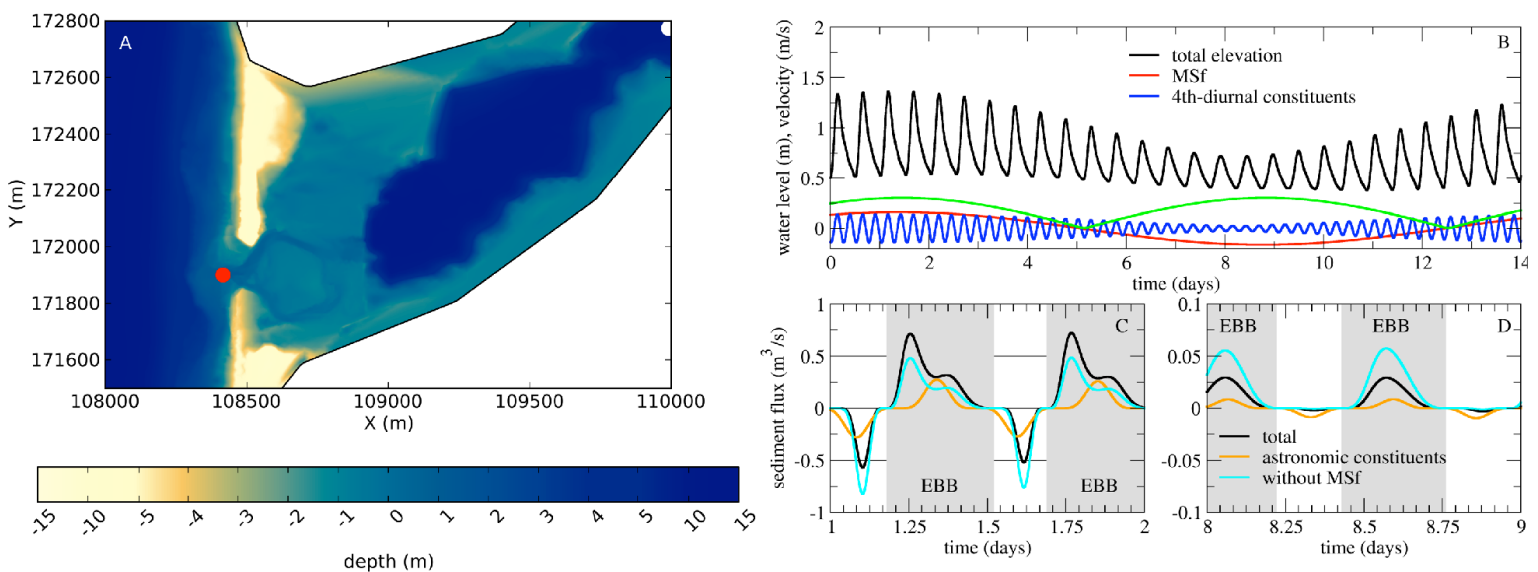

Figure 10 - (A) Batimetry of the Albufeira lagoon inlet, relative to mean sea level. (B) Water levels inside the lagoon obtained in a simulation forced by M2 and S2. MSf velocities at the inlet throat are also shown as a dashed line. Sediment fluxes across the tidal inlet estimated with the Engelund and Hansen (1967) formula on spring (C) and neap tides (D).

Figura 10 - (A) Batimetria da embocadura da Lagoa de Albufeira, relativa ao nível médio do mar. (B) Níveis dentro da laguna obtidos numa simulação forçada pelas constituintes M2 e S2. As velocidades associadas à constituinte MSf no centro do canal da embocadura são mostradas a tracejado. Os fluxos sedimentares através da embocadura foram calculados com a fórmula de Engelund e Hansen (1967) em marés vivas (C) e mortas (D). 


\section{Conclusions and future works}

This study presented a synthesis of the physical processes controlling the seasonal cycle of wavedominated inlets and revealed firstly that the inlet development during fair weather conditions was caused by a huge tidal distortion that promotes ebb-dominance. The shoaling or closure of wave dominated inlets during winter storm was explained by the superimposition of several wave-related processes: (1) the "bulldozer effect" due to the shore-normal component of wave forces acting over the ebb shoals; (2) the presence of lateral barotropic pressure gradients, accelerating longshore flows towards the inlet; (3) wave blocking during the ebb; (4) the reduction of ebb dominance by a high mean sea level in autumn and during storms; and (5) the presence of infragravity waves. In addition, fortnightly overtides generated by non-linear processes enhance ebb-dominance on spring tides and have the opposite effect on neap tides. This effect helps explaining the stronger tendency for inlet closure on neap tides. While the impact of processes (1), (2) and (4) on inlet morphodynamics were already quantified at the Óbidos Lagoon Inlet, the contribution of wave blocking and infragravity waves remains to be investigated. Also, this study mostly investigates cross-shore wave induced processes while oblique waves can induce strong inlet migration. The subsequent lengthening of the channel can alter tidal propagation and limit the ability of the inlet to flush sediments. It is expected that the proper representation of all these processes in morphodynamic modelling systems will allow simulating the closure of wave-dominated inlets.

However, hydrodynamic conditions display relatively modest variations along the West Coast of Portugal so that the physical processes analysed in this study may be partly site-specific. Their importance will have to be investigated at other wave-dominated inlets, such as in SW Australia, South Africa, California and Central and Southern America.

Also, other processes not discussed herein can affect the morphodynamics of tidal inlets. For instance, channel meandering increases the risk of inlet closure (Behrens et al., 2009, 2013), while fresh water flows promote its opening (Shuttleworth et al., 2005). Also, the curvature of the channel affects the inlet migration (Chaumillon et al., 2014). Overall, the morphodynamics of wavedominated inlets is a complex problem, and its controlling mechanisms remain only partly understood.

\section{Acknowledgements}

This work was part of a project funded by the Portuguese Foundation for Science and Technology (FCT): 3DMOWADI (PTDC/ECM/103801/2008). Researches in progress are part of the research project ANR JC DYNAMO (agreement ANR-12-JS06-00008-01). The wave models (SWAN) and the circulation models (ELCIRC/SELFE) were provided by Delft University of Technology and the Center for Coastal Margin Observation and Prediction, respectively. Topographic and hydrodynamic data were obtained, thanks to the combined efforts of many individuals from the Faculty of Science of the University of Lisbon, the National Laboratory of Civil Engineering, the University of Algarve and the Instituto Hidrográfico. The time series of sea surface elevation at Cascais were provided by the Portuguese Geographic Institute.

\section{References}

Behrens, D.K.; Bombardelli, F.A.; Largier, J.L.; Twohy, E. (2009) - Characterization of time and spatial scales of a migrating river mouth. Geophysical Research Letters, 36(9):L09402 . DOI: 10.1029/2008GL037025

Behrens, D.K.; Bombardelli, F.A.; Largier, J.L.; Twohy, E. (2013) - Episodic closure of the tidal inlet at the mouth of the Russian River - A small bar-built estuary in California, Geomorphology, 189(1):66-80. DOI: 10.1016/j.geomorph. 2013.01.017

Bertin, X.; Oliveira, A.; Fortunato, A.B. (2009a) - Simulating morphodynamics with unstructured grids: description and validation of a modelling system for coastal applications. Ocean modelling, 28(1-3):75-87. DOI: 10.1016/j.ocemod.2008.11.001

Bertin X.; Fortunato, A.B.; Oliveira, A. (2009b) - A modeling-based analysis of processes driving wave-dominated inlets. Continental Shelf Research, 29(5-6):819-834. DOI: 10.1016/ j.csr.2008.12.019

Bertin, X.; Fortunato, A.B.; Oliveira, A. (2009c) - Morphodynamic Modeling of the Ancao Inlet, South Portugal. Journal of Coastal Research, SI56:10-14, Coastal Education \& Research Foundation, Lisboa, Portugal. Available on-line at http://www.jstor.org/ stable $/ 25737527$

Bertin, X.: Bruneau, N.; Breilh, J.F.: Fortunato, A.B.; Karpytchev, M. (2012) - Importance of wave age and resonance in storm surges: the case Xynthia, Bay of Biscay. Ocean Modelling, 42(4):16-30. DOI: 10.1016/j.ocemod.2011.11.001

Booij, N.; Ris, R.; Holthuijsen, L. (1999) - A third-generation wave model for coastal regions. 1. Model description and validation. Journal of Geophysical Research: Oceans, 104(C4):7649-7666. DOI: 10.1029/98JC02622

Bruneau, N.; Fortunato, A.B.; Dodet, G.; Freire, P.; Oliveira, A.; Bertin, X. (2011) - Future evolution of a tidal inlet due to changes in wave climate, Sea level and lagoon morphology (Óbidos lagoon, Portugal). Continental Shelf Research, 31(18):19151930. DOI: 10.1016/j.csr.2011.09.001

Chaumillon, E.; Ozenne, F.; Bertin, X.; Long, N.; Ganthy, F. (2014) - Wave climate and inlet channel meander bend control spit breaching and migration of a new inlet: La Coubre sand spit, France. Journal of Coastal Research, SI70:109114. Available on-line at http://www.cerf-jcr.org/images/stories/ 2014_ICS_Proceedings/JCR_SI_70_019_Chaumillon_et_al.pdf

Dastgheib, A.; Roelvink, J.A.; Wang, Z.B. (2008) - Long term process-basedmorphological modeling of the Marsdiep Tidal Basin. Marine Geology, 256(1-4):90-100. DOI: 10.1016/j.margeo. 2008.10.003

Dodet, G.; Bertin, X.; Taborda, R. (2010) - Wave climate variability in the North-East Atlantic Ocean over the last six decades. Ocean Modelling, 31(3-4):120-131. DOI: 10.1016/j.ocemod. 2009.10.010

Dodet, G.; Bertin, X.; Bruneau, B.; Fortunato, A.B.; Nahon, A.; Roland, A. (2013) - Wave-current interactions in a wavedominated tidal inlet. Journal of Geophysical Research: Oceans, 118(3):1587-1605. DOI: 10.1002/jgrc.20146 
Dodet, G., (2013) - Morphodynamic modelling of a wave-dominated tidal inlet: the Albufeira Lagoon. 181p., PhD thesis, La Rochelle University, La Rochelle, France. Unpublished

Engelund, F.; Hansen, E. (1967) - A monograph on sediment transport in aluvial streams. 63p., Teknisk Forlag, Technical University of Danmark, Copenhagen, Denmark. Available on-line at http://repository.tudelft.nl/view/hydro/uuid\%3A81101b08-04b5-40829121-861949c336c9/

Fortunato, A.B., Oliveira, A. (2004). A modeling system for tidally driven long-term morphodynamics. Journal of Hydraulic Research, 42(4):426-434. DOI: 10.1080/00221686.2004.9728408

Fortunato, A.B.; Oliveira, A. (2007) - Case study: promoting the stability of the Óbidos lagoon inlet. Journal of Hydraulic Engineering, 133(7):816-824. DOI: 10.1061/(ASCE)0733-9429 (2007)133:7(816)

Fortunato, A.B.; Nahon, A.; Dodet, G.; Pires, A.R.; Freitas, M.C.; Bruneau, N.; Azevedo, A.; Bertin, X.; Benevides, P.; Andrade, C.; Oliveira, A. (2014) - Morphological evolution of an ephemeral tidal inlet from opening to closure: the Albufeira inlet, Portugal. Continental Shelf Research, 73:49-63. DOI: 10.1016/j.csr.2013.11.005

Friedrichs, C.T.; Aubrey, D.G. (1988) - Non-linear tidal distortion in shallow well-mixed estuaries: a synthesis. Estuarine, Coastal and Shelf Science, 27(5):521-545. DOI: 10.1016/02727714(88)90082-0

Hagemann, B.P. (1969) - Development of the western part of the Netherlands during the Holocene. Geologie en Mijnbouw, 48:373-388.

Oliveira, A.; Fortunato, A.B.; Rego, J.R.L. (2006) - Effect of morphological changes on the hydrodynamics and flushing properties of the Óbidos lagoon (Portugal). Continental Shelf Research, 26(8):917-942. DOI: 10.1016/j.csr.2006.02.011
Ranasinghe, R.; Pattiaratchi, C.; Masselink, G. (1999) - The seasonal closure of tidal inlets: Wilson Inlet, a case study. Coastal Engineering, 37(1):37-56. DOI: 10.1016/S0378-3839(99)00007-1

Roelvink, J.A.; Reniers, A.; van Dongeren, A.; de Vries, J. van Thiel; McCall, R.; Lescinski, J. (2009) - Modeling storm impacts on beaches, dunes and barrier islands. Coastal Engineering, 56(11-12):1133-1152. DOI: 10.1016/j.coastaleng.2009.08. 006

Roland, A.; Zhang, Y.J.; Wang, H.V.; Meng, Y.; Teng, Y-C.; Maderich, V.; Brovchenko, I.; Dutour-Sikiric, M.; Zanke, U. (2012) - A fully coupled 3D wave-current interaction model on unstructured grids. Journal of Geophysical Research: Oceans, 117(C11):C00J33. DOI: 10.1029/2012JC007952

Shuttleworth, B.; Woidt, A.; Paparella, T.; Herbig, S.; Walker, D. (2005) - The dynamic behaviour of a river-dominated tidal inlet, river Murray, Australia, Estuarine, Coastal and Shelf Science, 64(4):645-657. DOI: 10.1016/j.ecss.2005.04.007

Soulsby, R., (1997) - Dynamics of Marine Sands: A Manual for Practical Applications. 249p., Thomas Telford, Wallingford, U.K. ISBN: 978-0727725844.

Tung, T.T.,Walstra, D.J., Graaff, J. van de and Stive, M. (2009) Morphological modeling of tidal inlet migration and closure. Journal of Coastal Research (ISSN: 0749-0258), SI56:10801084. Coastal Education \& Research Foundation, Lisboa, Portugal. Available on-line at http://www.cerf-jcr.org/images/stories/1080. 1084_T.T.Tung_ICS2009.pdf

Westhuysen, A. (2012) - Spectral modeling of wave dissipation on negative current gradients. Coastal Engineering, 68:17-30. DOI: 10.1016/j.coastaleng.2012.05.001

Zhang, Y.; Witter, R.W.; Priest, G.P. (2011) - Nonlinear tsunamitide interaction in 1964 Prince William Sound tsunami. Ocean Modelling, 40(3-4):246-259. DOI: 10.1016/j.ocemod.2011.09. 005 